\title{
Gazeteci, Roman-Öykü Yazarı, Senarist Kimliklerinin Yanı Sıra Mistik Bir Şair Olarak: Ömer Lütfi Mete
}

\author{
Vedat Yeşilçiçek* \\ Uşak Üniversitesi \\ Fen Edebiyat Fakültesi \\ orcid.org/0000-0002-1994-5309
}

\author{
Hasan Hüseyin Gök \\ Uşak Sivaslı Tatar Ortaokulu
}

orcid.org/0000-0002-3837-7132

\section{$\ddot{O} z$}

1950-2009 yılları arasında yaşayan Ömer Lütfi Mete, gazeteciliğinin yanı sıra roman, hikâye, deneme ve senaryo yazarlığı da yapmıştır. Bütün eserlerinde İslam dinini ve milli değerleri ilham kaynağı olarak kullanmıştır. Ezan Sesi -Çizme-, Balonya Tüneli, Çığlı̆̆ın Ardı Çığlık, Asker ile Cemre, Yerden Göğe Kadar romanları, Allahsız Müslümanlık adını taşıyan deneme kitabı, Basılı Yakıt adını taşıyan hikâye kitabı bulunan Mete'nin televizyon dizisi olarak tasarlanmış Bizim Ev, Ekmek Teknesi, Kurtlar Vadisi, Kurtlar Vadisi Pusu, Kurtlar Vadisi Irak(sinema filmi), Deliyürek gibi senaryoları bulunmaktadır. Bestelenmiş şiirleri de bulunan Mete, şiirlerini 'Gülce' adlı eserinde bir araya getirmiştir. Üç bölüme ayırdığı bu eserinde, mistik duygularla kaleme aldığ̊ şiirlerinin yan sıra sosyal eleştiri taşıyan şiirleri de bulunmaktadır. Yanlış anlaşılan dini konulara ve geri planda bırakılmış milli değerleri sanat ve din anlayışının temeline oturtan Mete, tüm eserlerinde takındığı eleştirel tavırla dikkat çekmektedir.

Anahtar Kelimeler: Ömer Lütfi Mete, Mistik, Şiir, Din

\section{Journalist, Novel-Story Writer, Writer as well as A Mystical Poet: Ömer Lütfi Mete}

\section{Abstract}

Ömer Lütfi Mete, who lived between 1950-2009, has also written novels, stories, essays and script writings as well a journalism. He has used the İslam religion an national values as inspiration in all his Works. Mete has got Ezan Sesi-Çizme, Balonya Tüneli, Çı̆̆ı̆̆̆ın Ardı Çığlık, Asker ile Cemre, Yerden Göğe Kadar novels, Allahsız Müslümanlik trialbook. He also has got scenarions that are desingned for to series such as Bizim Ev, Ekmek Teknesi, Kurtlar Vadisi, Kurtlar Vadisi Pusu, Kurtlar Vadisi Irak (cinema movie), Deliyürek, poems, brought his poems together in his work 'Gülce' in his this work, which consists of three divisions, there are poems bearing social criticism as well as poetry which he wrote who based on kept in back ground national values and based on understanding of art and religion, draws attraction with his critisim in his works.

Keywords: Ömer Lütfi Mete, mystic, poetry, religion 


\section{GİRIŞ̧}

\section{1. Ömer Lütfi Mete'nin Hayatı}

2 Şubat 1950'de Rize -İyidere'de doğar. Ömer Lütfi Mete'nin babası, İyidere'de Meteler adıyla bilinen aileye, annesi ise Trabzon Of ilçesi eşrafından Sarallar ailesine mensuptur (Gök, 2016) ${ }^{1}$. Ailesi ve çevresinde dini bir hayat idrak eden Mete'nin dedesi de Süleyman Hilmi Tunahan cemaatindendir. Ailenin en büyük çocuğu olan Mete'nin, bu atmosferde büyüdüğü görülür. Bu konuda yakın arkadaşı olan Okumuş şu tespiti yapmaktadir:

"Babası ve annesi evinden çok buradaki Kur'an kursuna himmet eden insanlardı"

(Okumuş, ADP, 2011)

Ömer Lütfi Mete bir süre bu kurslarda eğitim gördükten sonra on dört yaşlarında yine bu kurslarda hocalık yapacaktır (Gök, 2016). Yoğun bir eğitim ve öğretim süreci içerisinde geçen çocukluğu ona 'çocukluğunu yaşama' olgusundan uzaklaştırır. Gazeteci arkadaşı Ahmet Tezcan onun bu eksikliğini şu cümlelerle dile getirmektedir:

“Çocukluğunu yaşamamış pek. Çocukluğu tespihin, takkenin ve kitabın 'suç unsuru' sayıldığı arabesk faşizm döneminde, gizli gizli Kur'an ve Arapça öğrenmeye çalışarak es geçilmiştir. Çocukluğuna hasretti bu yüzden" (Tezcan, 2010:17).

Mete'nin daha sonra yayımlayacağı 'Ezan Sesi' (Çizme) romanı konusu da bu döneme ait hatıraların ve gözlemlerin ürünüdür. Bu roman, 1991 yılında sinemaya da uyarlanacaktır.

Üniversite yıllarında kaybettiği annesinin, hayat ve sanat anlayışında tıpkı dini ilimlerin olduğu gibi önemli bir yeri vardır. Ancak annesinin beklenmedik ölümü Mete'nin üniversite öğrenimini yarıda bırakmasına neden olacaktır.

1982 yılında Leyla Hanımla evlenir. Bu evlilikten Ali Buhara, Fatma Berra, Hatice Hicaz ve Zeynep Mücteba isminde dört çocuğu olur. Oğlu Ali Buhara, bir baba olarak Ömer Lütfi Mete'yi şöyle anlatmıştır:

"Bir erkek çocuğu için baba figürü hayattaki en önemli şeylerden bir tanesidir. Tabi sizin babamı tanıdığını kadar ne kadar kendine münhasır bir şahsiyetse, benim için de ve ailemiz için de aslında o kadar sıra dışı bir insandı. Etrafa baktığım zaman onun çok farklı bir baba olduğunu görmek zor değildi. Çünkü bizlere çok farklı şekilde yaklaşırdı. Bizleri bir birey olarak görürdü. Böyle bir insanın yanı başımda olması benim için hayatımda en büyük kolaylıklardan bir tanesiydi. Doğruyu ve eğriyi öğrenebilmem için çok fazla uzağa gitmeme gerek kalmazdl. Tabi kendisi çok neşeli bir insandı. Özel bir insandl. Bizlerle uğraşmayı çok fazla severdi. Bizlere takılmaktan keyif alırdı. Giderken bile çok fazla şey öğretti. Birçok şeyi sorgulamama, düşünmeme sebep oldu" (Kartal ve Batuhan, 2010:48).

\footnotetext{
${ }^{1}$ Eşi Leyla Mete ile 2016 yılında yapılan mülakattan alınmıştır.
} 
Samimi bir inanç dünyasında yetişen Mete'nin Allah sevgisi ve imanı, en belirgin özelliği olarak karşımıza çıkmaktadır. Bütün hayatını bu ilke çerçevesinde şekillendiren Mete, İslam' in yanlış anlaşılması veya yorumlanmasından kaygı duyan bir mütefekkir kimliği ile karşımıza çıkar. Bidatlara sürüklenen Müslüman camiasından bir düşünce adamı olarak çok endişelenmiş ve inandığı doğruları çok eleştirilse de söylemekten ve yazmaktan kaçınmamıştır. Bu anlamda kaleme aldığ 'Allahsız Müslümanlık' adlı eseri sert eleştiriler almasına neden olacaktır. Ancak dirayetli bir mümin özelliği barındıran Mete, kızının tabiri ile "Allah var, gam yok" der ve bildiği yolda yürürdü (Gök, 2016).

Sürdürdüğü bu imanlı ve velut hayat, 1986 yılında tanıştığı Harputlu Şeyh Tayyar Baba'nın torunu Abdülkadir Şaşmaz Efendi'nin etkisiyle daha derin ve anlamlı bir çerçeveye oturacaktır (Ö.L.M. Bel. TRT, 2012). On dört yaşında Kur'an hocalığı, on yedi yaşlarında yaşadığ İyidere ilçesinde vaizlik gibi önemli görevler ifa eden Mete için bu tanışma, bilgide ve öğrenmede derinleşmenin, kemale ermenin önünü açacaktır. Bu aktif ve bir o kadar da sancılı süreçte Rize Ülkü Ocakları Başkanlığı da yapan Mete için akrabası olan Muhsin Mete; "Türk-İslam sentezini gerçekleştirmişti" (Mete, 2010, s.9) değerlendirmesini yapmaktadır. Ülkemizin o süreçte geçirmiş olduğu sosyal ve siyasal olayların etkilerini taşıyan bu evrilme süreci, aslında Mete'nin iç dünyasında yaşadığı arayışların bir yansıması olarak algılanmalıdır.

Yine Kuveloğlu, Mete'nin bu tavrı ile ilgili:

“Ömer Lütfi Mete, zamanımızın insanın her alanda yaşadığı erozyon ve yozlaşmaya inat, geçmişten günümüze uzanan bir köprü gibiydi. Geçmişten gelen ve bizi biz yapan değerlerin zerresini kaybetmeyen büyük bir değerdi. Türk Milletinin harcına ve harsina bağhl; Türk milletini aziz ve necip millet yapan değerlerle gurur duyan bir dava adamıydı" (Kuveloğlu, 2010:11) tespitlerini yapar.

Tavrı, bilgisi ve duruşuyla ön plana çıkan Mete, dönemin Ülkü Ocakları Başkanı olan Muhsin Yazıcıŏ̆lu'nu da etkileyecek, hatta bu durum Alparslan Türkeş'e iletildikten sonra Türkeş'in talimatıyla Mete'nin bilgi ve tecrübelerinden teşkilatların faydalanması istenecektir (Okumuş, ADP, 2011).

1970 yılında İstanbul Üniversitesi İktisat Fakültesine kaydolur. Bu dönemde Şeref Oğuz'un yayın yönetmenliğini yaptığı 'Dünyada ve Türkiye'de Sabah' gazetesinde çalışmaya başlar. Yukarıda da belirtildiği gibi annesinin ölümü bu eğitimi tamamlamasını engelleyecektir. Ancak okuduğu üniversitedeki sosyal ortam, karşılaştığı kişiler ve hayat tarzları da Mete'yi üniversiteden uzaklaştıran başka nedenlerdir (Gök, 2016).

Bunun üzerine 1974 'de Marmara Üniversitesi Eğitim Fakültesi Türkçe Öğretmenliği bölümüne kaydolur. Bu yıllar, ülkeyi kasıp kavuran sol merkezli siyasi akımlara karşı 'ülkücü' kimliğinin pekiştiği yıllardır (Mete, 2007, s.9). Buradan mezun olan Mete, memleketi Rize'de öğretmenliğe başlar (Ö.L.M. Bel., TRT, 2012). Mete'nin bir nevi özeleştiri getirdiği romanı 'Balonya Tüneli' adlı eseri de bu döneme ait eserlerindedir. 
Terzi çıraklığı, matbaa iş̧̧iliği, çeşitli dergi ve gazetelerde mizanpaj sorumluluğu, gazetecilik, öğretmenlik, muhabirlik, spor yazarlığı, genel yayın yönetmenliği, senaristlik gibi çeşitli alanlarda çalışmış ve ürün vermiş olan Ömer Lütfi Mete, bütün bunların birleştiği bir alan olan 'ediplik kimliği' ile ise daha kalıcı eserler vermiştir. 2009 yılında vefat eden Mete, geride bıraktığı bu zengin ve başarılı edebi mirasa rağmen halen gerekli ilgiyi görmüyor olması üzerinde durulması gereken bir husustur.

\subsection{Sanatı ve Sanat Anlayışı}

Ömer Lütfi Mete'nin sanat ve sanat anlayışını kuşatan iki cepheden bahsetmek mümkündür:

- Çocukluğundan beri hayatını kuşatan 'dini iklim',

- Daha sonraki yıllarda bir sentez olarak algıladığı 'milli iklim'.

Eserlerinin hemen tümünün ilham kaynağını oluşturan ve Mete'nin ruh dünyasında coşkun iki nehir gibi akan bu iki temel unsur, yaşadığı sosyal hayatın gerçekleri ile karşılaştığında, ruhsal anlamda sert bir kayaya, derin bir yara düşmüş gibi olur. Mete, bu süreçte öğrendikleri, bildikleri ve inandıklarıyla yaşadıkları ve gördükleri arasındaki derin uçurumu hiç çekinmeden 'eleştiriye' dönüştürür. Bilgili, derin ama sivri dilli bu kalem elbette beklendiği gibi hemen sanat ve edebiyat çevrelerinden dışlanacak, görmezden gelinecektir. Bütün hayatını 'nehy-i ani'lmünker' prensibi üzerine oturtan Mete'nin karşılaştığı bu durum manen değilse de madden hayatı boyunca ona sıkıntı olarak yansıyacaktır.

Anlatma, yazma, üretme tutkusu ile geçen kısa ömründe birçok eser vücuda getiren Mete, kendi tabiri ile sırtını hep bu aziz millete ve onun birikimlerine yaslamıştır. Dolayısıyla hemen hemen bütün eserlerinde görülen didaktik tavrı çok sevdiği milletine doğruları anlatma çabasından neşet eder. Fikir yazılarını bir yana bırakacak olursak romanları, öyküleri ve bu çalışmamızda tematik özellikleri bakımından inceleyeceğimiz şiirlerinde, hep bu tavrı görmek mümkündür. Bu arzu ile 1978 yılında çok sevdiği öğretmenlik mesleğini bırakarak 1980-1986 yılları arasında Tercüman gazetesinde çalışır. Eriş, onun bu sorgulayan ve mücadeleci ruhunu şöyle anlatır:

\footnotetext{
“Bu millete neden ters düşülür? Çă̆̆ yakalamak doğru hedeftir ama değer hükümlerimiz neden inkâr edilerek bir yerlere varılmaya çalışılır? Ve yillardır rejim tarafindan ısrarla itilen- kakılan halk çoğunluğu ile halkının temel değerlerine bağl münevverlerimiz neden bazı sosyo- kültürel olayların, özellikle çă̆daş sanat dallarının içinde olamamış, dışında kalmışlardır? Gönül bağıyla bağlı olduğu münevverler sinema, tiyatro yani drama dünyasında neden ağırliklı olarak bulunmuyorlar? İşte yetişkinlik yillarında bu sorular Ömer Lütfi'nin kafasında dolanıp durmuştur" (Eriş, 2010:29).
}

Aynı süreçte ve aynı saikle, Türk Edebiyatı Vakfı ve Boğaziçi Kültür ve Sanat dergilerinde yazılar yayınlamaya devam eder. Bu kültür aktivitelerinin kaynağı ise Tahsin Banguoğlu'nun kurduğu 'Aydınlar Ocağı'(1970) olduğu gözden kaçırılmamalıdır. 
Belli hassasiyetleri dışında, yakınları tarafından tespit edilmiş nev-i şahsına münhasır davranış ve anlayışlara sahip olan Mete'nin yakınları, onun bu konulardaki farklılığ için 'sürekli ev değiştirmesini ve çantasında sürekli elma taşımasını' örnek göstermektedirler (Gök, 2016).

Karakteristik bir özellik olarak buraya aldığımız bu hayat tarzı ve davranış tarzları Mete'nin eserlerine de yansır. Türk televizyon tarihinin en çok izlenen dolayısı ile en çok ilgi gören dizilerinden biri olan Kurtlar Vadisi' dizisinin senaristliğini yapan Mete, burada hayat verdiği 'Zaza' karakterine sürekli elma yedirmesi kendisinden kaynaklı bir imge olarak karşımıza çıkar. Yine aynı dizide kendi gerçekliğinden yola çıkarak hayat verdiği 'Ömer Baba' karakteri bu anlamda önemlidir. Dini ve milli birikimi ile bir 'bilge' kimliği taşıyan 'Ömer Baba' o güne kadar Türk televizyonlarında görülmeyen bir karakteri insanımızın hayatına taşımıştır. Yaşanan olaylara dini konulardaki derin bilgisi ve milletine karşı duyduğu derin sevgisi ile yaklaşan ve ana karakterlere en sıkıştıkları zamanda yol göstermeyi başaran bu 'bilge' kişilik, Mete'nin belki de çok özlediği toplumsal yapımızın prototipi olma özelliğini taşır.

Türk Edebiyatı Dergisi'nde çalışan Mete'nin İsa Kocakaplan ile münasebeti de edebi yönünün gelişmesinde etkili olacaktır. Hem Kocakaplan hem de bir başka dostu olan ve 'Basılı Yakıt' adlı eserinin editörlüğünü yapan Cem Sökmen, Mete'nin özellikle 'Kurtlar Vadisi' adlı dizinin senaryosunu yazarken, Türkiye'nin hem o anki hem de gelecekteki gündemini yakalayabilme becerisine vurgu yaptıklarını görüyoruz (Gök, 2016).

Konuşmalarında ve eserlerinde her zaman doğruyu söyleme - yazma- bilinciyle hareket eden Mete'nin, taviz vermeyen, sert dilli bir yazar olduğu algısı da yaygındır. Bu konuda Umur Talu:

\footnotetext{
“Ömer Lütfi Mete ile herhalde apayrı yolların yolcusuyduk. Bizi en azından vicdanla buluşturan temelde de öyle bir şey vardı. "Boyun eğmeme gayreti. İktidar, başkan, komutan, patron, iş dünyası, 'yerüstü ve yer altı zenginlikler' karşısında boyun eğmeme inadi. Ama hepsine birden; öyle seçerek, tek tek basaraktan, kimine efe, kimine kul olaraktan değil. Otoriteye, tahakküme, direnme damarı. Onunki Karadeniz'le de sertleşmiş; bizimkinde belki kana karışış"(Kartal ve Batuhan, 2010) tespitlerini yapar.
}

Mete'de yaşam biçimi haline gelmiş olan bu tavır, onun sanatını ve edebi hayatını da kuşatacaktır. Zaten Mete'yi diğerlerinden ayrıştıran, özelleştiren de bu doğrucu ve dik tavrıdır. Bu yüzden Ayla Ağabekim onun hakkında 'satmayan ve satılmayan adam' nitelemesini yaparken, Ekrem Kaftan ise onu 'kendini dünyaya yabancr hissetmiş' (Kartal ve Batuhan, 2010) nitelemesini yapacaktır.

Ömer Lütfi Mete daha önce belirtildiği gibi, öğrendikleri ve inandıkları ile yaşadıkları ve gördükleri arasında tezat yaşar. $\mathrm{Bu}$ onu yaşadığı dünyaya yabancılaştırır. Ancak münzevi bir hayat yerine Mete, dirençli, itiraz eden doğruları her yerde söylemeyi prensip edinmiş bir hayatı seçer. 
Mete, Tercüman'dan ayrıldıktan sonra 'Yeni Haber' adlı bir gazete çıkarır. Uzun ömürlü olmayan bu teşebbüsten sonra Ankara'ya gidecek, Belediye Başkanı Mehmet Altınsoy'un teşvikiyle 'Belde' adlı bir gazete çıkaracaktır. Bu deneyim de uzun sürmez ve tekrar İstanbul'a dönerek 1987 'de Türkiye Gazetesi'nde spor müdürlüğü görevini üstlenir. Böylece çok farklı bir yönü de neşv ü nema bulmuş olur. Fanatik bir Galatasaray taraftarı olan Mete için arkadaşları olan Hasan Kaçan (Kaçan, ÜBAP, 2009), Bahadır Özdener (Özdener, ÜBAP, 2009) onun haftalık halı saha maçlarını da kaçırmadığını ifade ederler.

Mete, yakın dostu olan Nazif Okumuş'un daveti üzerine bir süre sonra Ortadoğu gazetesinde köşe yazılarına başlar. 1993'te TGRT'de 'Yanı' adlı bir haber programı yapar. Aynı süreçte 'Yeni Şafak'ta köşe yazıları yazmaya başlar. Ancak doğrucu kimliği burada da başına dert olur. 'Hamas'ı eleştiren bir yazısından dolayı Yeni Şafak'tan ayrılmak zorunda kalır. 1996' da kurulan ve sadece bir yıl yayında kalan 'Yeni Sayfa' gazetesinin yayın yönetmenliğini yapar. 'Yeni Bin Yıl'da da yazılar kaleme alır. Namık Kemal Zeybek'in yayınladığı 'Ayyıldız' (1998-1999) da yazı yayınlar. 2000'li yıllarda Sabah'ta yazan Mete daha sonra ise 'Bugün' de köşe yazıları yazar (Ö.M.L. Bel. 2012).

Sinema ve televizyon dünyasının içerisinde olan İsmail Güneş'le tanıştıktan sonra senaryo çalışmalarına hız verir. Mete'nin bu alandaki kabiliyeti için Güneş:

\begin{abstract}
“Onun büyük bir daktilosu vardı. Çok da hızlıydl, pratik yazardl. Sekiz bölüm yazmışık. Kısmet olmadı onu çekmek ve öyle devam etti. Aşağı yukarı Bizim Ev o senaryonun versiyonudur. Fakat onun öncesinde Veysel Karani, Ahmet Bedevi filmlerinin senaryosunu o yazdı ben de yönetmenliğini yaptım. Bizim Ev dizisi o dönemde en çok devam dizi olmuştur. 101 bölüm sürdü. Dizi devam edecekti fakat o zaman 28 Şubat süreci olduğu için baskılar gelmeye başladı. Bize bu doğrudan söylenmiyor fakat dolaylı bir şekilde anlatmaya çalışıyorlardı. Filmi absürd bir finalle bitirdik. Filmin imamı Salih Kırmızı hiçbir sebep yokken tutuklandı. Salih Kırmızı imamliğın dışında pek çok şeyle ilgili olan bir kişidir. Çocuklarla futbol oynar, okulun çatısını aktartır vs" (Güneş, 2011, https://www.youtube.com/watch?v=JW4QX-G8xSQ) tespitlerini yapar.
\end{abstract}

Ömer Lütfi Mete'nin senaristliğini yaptığı 'Bizim Ev'in laiklik karşıtlığ1 sebebiyle yayından kaldırılması İsmail Güneş'i çok etkiler. Başka dizilerde başka din adamları hiç problemsiz yer alırken, Müslüman din adamlarının diziye konu edilmesine karşı çıkmaları Güneş'i Sirkeci'den Cağaloğlu'na papaz kıyafeti ile yürüyerek kararı protesto etmesine vesile olur. Mete'nin İsmail Güneş'le birlikte bir diğer çalışması Ezan Sesi-Çizme- adlı sinema filmidir. Film ezanın Türkçe okutulması garabetini konu eder. Bu konuda Erdoğan:

"Ülkenin değişik ırk, renk ve inanıştaki insanların yönetecek kimseler, milletin manevî değerlerini her zaman iyi etüt etmeli ve bu değerlerle asla çatışma içine girmemelidir. Bu, hem demokrasi anlayışının hem cumhuriyetçiliğin hem de insanlığın bir gereğidir" (Erdoğan, 2010:8) tespitlerini yapar.

Aynı ikili 1980 ihtilalini yeren 'Gülün Bittiği Yer' filmini çekerler. Son olarak da ‘The İmam'ı sinemaya aktarırlar. Film, Mete'nin hayatı boyunca yaptığı mücadelenin 
özeti gibidir. Eser dini yanlış anlamış, yobaz, tutucu Hacı Feyzullah Hoca ile dini hoşgörü çerçevesinde, gerçek değerleriyle anlayan ve halka anlatan Emrullah'ın hikâyesinden, çatışmasından ibarettir.

'Mevlana' adlı bir senaryo yazan Mete, bu senaryoyu Konya Belediyesi'ne teslim etse de farklı gerekçelerle sinemaya aktarılmamıştır (Gök, 2016).

Mete'nin sinema yanında dizi senaristliği de bu süreçte devam edecektir. 'Bizim Ev' dizisi ile başlayan bu dönem, 'Deliyürek', 'Hayat Bağları', 'Ekmek Teknesi', 'Kurtlar Vadisi', 'Kurtlar Vadisi Pusu', 'Eşref Saati' gibi yapımlarla devam edecektir.

Mete'nin bu yapımlarla yarattığı ilgi ve alg1 değişikliği gözden kaçırılmamalıdır. Deliyürek'teki 'Kuşçu', Ekmek Teknesindeki 'Fırıncı Nusret Baba', Kurtlar Vadisi'ndeki ‘Ömer Baba' vb. karakterlerin izleyiciye taşıdığı milli ve manevi değerler o güne değin hiçbir televizyon yapımının yapmadığı, yapamadığı özellikler barındırır. İzleyicinin karşısına dini ve milli bilgileri ile ve bir 'bilge' kimliğiyle çıkan bu karakterler, toplumun çoktan beridir özlediği, beklediği rol-modelleri ihtiva eder. Çocukların ve gençlerin bir prototip olarak benimsediği bu karakterler, olay örgüsünün içerisine, milli ve yerli değerleri bütün ihtişamı ve güzelliği ile yerleştirmeyi hedefler. Mete, yarattığı bu karakterler yoluyla, sosyal hayatımızın içerisinde var olan çarpıklıkları, yanlış bilgileri, yanlış davranışları, yanlış yorum ve algıları, sabır, metanet ve bilge kimliklerinin kuşattı̆̆ bir anlayışla izleyiciye sunar. Özlenen ve beklenen sosyal yaşamın, dini hayatın muhabbetini izleyicilerle buluşturur. Bu son derece orijinal uygulama, toplumdaki 'iyi' olgusunu öncelerken 'kötü'yü terk ettirmeyi hedefler.

Bu anlamda Murat Çeri'nin şu tespitleri önemlidir:

“Günümüzde güzel söz söylemek değildi asıl olan, trajedi ve dramlarla süslemek de değildi marifet; marifet 0-12 yaş grubuna hitap eden aptal kutusunun içine irfanı sokabilmekti. Yilların bilgeliğini sığdırabilmekti. Yok olmaya yüz tutmuş aile kurumunu ayakta tutmaya çalışmak, mertliği, dürüstlü̈̆̈̈, dindarlı̆̆ı ve vatanı sevmeyi yüreğe, yüreklere nakşetmektir"(Çeri, 2010:27).

Yine Mete'nin özlediği dünyanın özeti olan ve duaya dönüşerek 'Kurtlar Vadisi Irak' filminde Şeyh Abdurrahman Kerküki'nin ağzından izleyiciye ulaşan şu sözleri bu anlamda önemlidir:

"Yarabbi! İşittik ve itaat ettik. Allah işinde muhakkak ki galiptir. Görünen ne olursa olsun, kim yenerse yensin, kim yenilirse yenilsin galip olan, hâkim olan, yapan ve yaptıran sensin. Ya Rab! Sen ki Muhammed Mustafa'ya dahi yenilgi sinavin yaşatansin. Sen zulmetmezsin Ya Rabbi! Inandik ve tasdik ettik. Zulmeden biziz Ya Rabbi! Senin yolunda kenetlenmeyip ayrı düştü̆ğ̈müz benlik hevesinde bölündü̆̆̈̈müz için kendimize zulmettik. Biz, bize zulmettiğimiz için düşman da bize zulmediyor. Bütün zalimlerden ve senden sana sığındık Yarabbi! Bizler gafil olduk, günahkâr olduk, mahkûm olduk, mağlup olduk. Kur'an ve Sünnetin hikmetleri ile uyanmadık. Sen bizi düşmanın saldırllarıla uyandırdın. Şimdi de lütfet Yarabbi! Bize bu saldırlları defedecek güç ve enerji ver. Bilinçli sabır ve sebat ihsan eyle. Yarabbi! Bize barış dini İslam'ı getiren peygamberin hürmetine, onun mecbur kalıp 
savaştığı zaman titizlikle sadık kaldığı vuruşma hukuk ve ahlakından ayırma Yarabbi!"(Kurtlar Vadisi Irak Filminden alınmıştır).

Hikâye, roman ve deneme yazarlığı da yapan Ömer Lütfi Mete'nin bu yönü hep geri planda kalmıştır. 1978'de ilk romanı 'Balonya Tüneli' romanını, ardından 'Ezan Sesi-Çizme' romanını, yine 'Asker ile Cemre', 'Yerden Göğe Kadar', 'Çı̆̆lığın Ardı Çı̆̆lık', 'İtfaiye Yakıyor' adlı romanlarını yayınlar. Ancak kısa ömrüne sığdırdığı bunca eserde olduğu gibi bu türde verdiği eserlerde de az önce belirtildiği gibi hak ettiği ilgiyi göremeyecektir.

'Hacı Yağı ile Parfüm Arasında”, “Allahsız Müslümanlık' gibi deneme kitapları ile 'Basılı Yakıt' adlı hikâye kitapları da benzer kaderi paylaşacaktır.

\section{Metafizik Bir Şair Olarak Ömer Lütfi Mete}

Mete'nin yukarıda belirttiğimiz özelliklerinin yanında yine ön plana çıkmayan, kısıtlı çevrelerce bilinen şairlik kimliği de oldukça güçlüdür. Kendine özgü ve o oranda orijinal özellikler taşıyan şiirler kaleme alan Mete, bu türde de toplumsal fayda prensibini esas edinmiş, öğretici, yönlendirici metinler kaleme almıştır. Tasavvufi derinliğin kuşattığı aşk konulu şiirlerinin yanında, toplumsal eleştiri kaynaklı eserler de kaleme alan Mete, sürekli olarak, yaşadığı ve ait olmaktan şeref duyduğu milletin ve içine doğduğu medeniyetin gelişmesi için çabalamıştır. Bu anlamda, eserlerinde, yaşanılan sosyal ve siyasal buhranlardan bir aydın duyarlılığı ile müteessir olan anlayışla karşımıza çıkar. Diğer türde yazdığı eserlerinde olduğu gibi şiirlerinde de yerli ve milli bir duyuş ve düşünüşle, bize özgü bir medeniyet tasavvurunun hudutlarını yansıtmaya çalışmıştır. Mete, bu anlayışla farklı dergi ve gazetelerde yayınlamış olduğu şiirlerini daha sonra 'Gülce' adlı eserinde bir araya getirmiştir.

Gülce adlı şiir kitabında kendisi şiirlerini tematik yapılarına göre tasnif etmiştir. Üç bölümlük bu tasnif:

- Leyla Bahsi

- Dünya Bahsi

- Mevla Bahsi

Olarak adlandırılmıştır. Bu kitapta yer alan;

'Yusuf İdim Davut Oldum', 'Yiğidi Gül Ağlatır', 'Bu Şehir Girdap Gülüm', 'Şehidin Destanı', 'Üç Ayak Bir Şafak', 'Gülün Bittiği Yer', 'Olmaz Olsun' başlıklı şiirleri bestelenmiştir. Bu şiirlerden Üç Ayak Bir Şafak Osman Öztunç, Gülün Bittiği Yer Haluk Levent, Yiğidi Gül Ağlatır Fatih Kısaparmak tarafından bestelenmiş ve yine aynı sanatçılar tarafından icra edilmiştir/mektedir.

Mete'nin 'Gülce' ismini taşıyan şiir kitabının 'Leyla Bahsi' bölümündeki ilk şiir -Gülce- kitaba da ismini veren şiirdir. Mistik bir derinlik taşıyan bu şiirde, şairin Necip Fazıl'ın düşünce buhranlarına benzer bir çatışmanın içerisinde yaşadığı görülür. 'Var' ile 'yok' arasında ya da bu dünya ile öte dünya arasında yaşanan bu metafizik buhranlar, Mete gibi dini bütün şairlerde bu dünyanın onlarda yaşattığ1 korku ve vehimle vücut bulur. Çetin(2014) bu mistik tavrı şöyle tanımlar: 
"Mistisizm genelde insanın kendisini üstün, seçkin, tapılası ve değerli niteliklere sahip olduğuna inanılan yüce bir varlıkta, düşüncede ya da kavramda bütünüyle eritmesi ve ondan yok olması, kendini tamamıyla ona vermesi halidir" (Çetin, 2014:31).

Çetin' in vurguladığı 'onda yok olması' hali zaten tasavvuftaki yok da yok olma halinin tanımıdır. Mete'nin

Uçurumun kenarındayım Hızır

Ulu dilber kalesinin burcunda

Muhteşem belaya nazır

Topuklarım boşluğun avucunda

Derin yar adımı çă̆ııır

$\cdots$

Uçurumun kenarındayım Hizır

$\cdots$

Başım döner, beynim bulanır

El etmez

Gel etmez

Gülce'm uzaktan dolanır

Uçurumun kenarındayım Hizır

$\cdots$

Yar yüzünde infaz

Bir gamzelik rüzgâr yetecek

Ha itti beni, ha itecek

Güzelliğin zulme çaldığı sınır

Uçurumun kenarındayım Hızır

...(Mete, 2011:8)

Mısralarındaki anlam derinliği 'yok da yok olma' isteğinin 'var'daki buhranı yaşama halidir. Şairlerin, inançlarından hareketle yaşadıkları bu ruh devinimleri, inanç sistematiklerindeki mukavemete göre şekillenir. Türk şiirinin usta kalemi Haşim de;

Ölmek

Firaz-ı zirve-i Sina-yı kahra yükselerek

Oradan

Oradan düşmek ölmek istiyorum

Cevf-i ye's aşina-yı hüsrana (Akyüz, 2017:618). 
Derken, bir buhranın içinde yaşadığının işaretini verir. Ancak dini duyguları kaybeden (Kaplan, 2012:142) Haşim'in yaşadığı buhran şahsi bir psikolojik durumun dişa vurumudur. Yine, Tevfik Fikret

Inanmak İhtiyact

Bütün boşluk: zemin boş, asuman boş, kalb ü vicdan boş

Tutunmak isterim, bir nokta yok piş-i hasarımda

$\cdots$

Bu yalnizlik, bu bir gurbet ki benzer gurbet-i kabre...

İnanmak işte bir aguş-i ruhani o gurbette (Fikret, 2015:219)

Derken düştüğü buhranı dile getirir. Bu örnekleri çoğaltmak mümkündür. Nitekim yine Cumhuriyet Devri Türk şiirinin büyük kalemi Necip Fazıl'ın kitabına adını veren 'Çile' baştan sona bir düşünce buhranının vehimle buluştuğu travmatik alanları işaret eder. Ancak burada İslam inancıyla perçinlenmiş Necip Fazıl, Mete gibi ruh ve duygu insanlarının korku ve vehimleri az önce ifade edilen 'yok da yok olma' arzusunun ateşlediği ruh halidir.

Mete'yi uçurumun kenarına iten ve Hızır'dan yardım dileyen hali bir 'acz' hali olmaktan çok bir 'mecz' halidir. İnsani hiçbir korkusu olmayan, hatta Deccal'den, yedi düvelden korkmayan bu ruh, mutlak güzele kavuşmanın arzusuyla düştüğü ruh deviniminden 'tir tir' titremektedir.

Aslında tüm bu ruh hali, içine düşülen ve bütünüyle tanımlanamayan 'aşk' halidir. Maşuk'a kavuşma arzusunun tecelli ettiği bu ruh halinde korku ve vehim içsel bir devinim olarak ortaya çıkar. Bu metafizik algının içine düşen ruh kendisini 'çaresiz' ve boşlukta hisseder. Şairin sık sık tekrarladığı ve şiirin izleği konumunda olan 'Uçurumun kenarındayım Hızır' dizesi böyle düşünüldüğünde anlam bulacaktır.

Mete'nin bu şiirde yarattı̆̆ı metaforik atmosfer bizi bütün yönleriyle 'tasavvufi' bir buhranın derinliklerine taşır. Şair, büyük bir uçurumun boşluğuna benzettiği metafizik tutkusunu- aşkını- duyumsarken, yaşadığı gerçek hayatın kötülüklerinin, faniliğinin farkına varır. Bu durum onu mutlak iradenin karşısında acze düşürür. Bu 'bela' onda derin buhranlar yaratır. Hızır'dan yardım dilemesi onun ruh dünyasında geldiği 'yok da yok olma' arzusunu ortaya koymaktadır. Ötelerden aldığı davet şiirine,

Mecaz değil

Gülce bir davet

Maraz değil

... (Mete, 2011:9)

Mısraları ile yansır. Mete'nin 'mecaz değil' diyerek vurgu yaptığı 'beşeri bir duygu durumundan çok 'tanımlayamadığı, metafizik âleme ait ancak 'hakiki' bir aşkın tezahür ettiği bir halin anlatımıdır. 
Benzer bir durum da 'Yar' adlı şiirinde karşımıza çıkar. Türk Halk edebiyatının mani türünü anımsatan bu şiirde, 'aşk, yar, ok, yara, sır, gam, zehir' gibi anahtar kelimeler bizi Mete'nin tasavvufi dünyasına götürür.

Yara beni yara beni,
Aşkın oku, yara beni,
Bıraksınlar yara beni,
Atsın yardan, yara beni,
Yara beni, yara beni,
...
Azığım zehir
Bineğim gamdır,
...
Hem ilaçtın hem yaraydın

Sırrımı deşip yaraydın (Mete, 2011:22).

Mete'nin yukarıdaki dizelerinde sık sık tekrarladı̆̆g 'yar/a' kelimesi, şiirin duygu dünyasını kuşatıp anlamlandıran anahtar kelime olarak karşımıza çıkmaktadır. Bu kelimeyi 'ok, zehir, gam, sır' gibi kelimelerle bütünleştiren şair, şiire mistik bir atmosfer kazandırır. Tevriye sanatının imkanlarını kullanarak yarattığı metaforik çağrışımlar, bize şairin tasavvufi kimliğinin derinliklerini hatırlatır. Bir aşk yarasından muzdarip olan şair, şiirin bütününe bakıldığında Fuzuli'yi hatırlatan bir erdemle aşkı ele alır. Dolayısıyla bu durumdan -aşk acısı çekmekten- hoşnuttur. Bu tasavvufi hal aslında 'kemale' ermenin yoludur ve Mete, aslında bu yolun bir yolcusu olma halinden memnundur. Çektiği acı, gam ve sinesinde açılan yaralar onu olgunlaştıracak ve mutlu sona taşıyacaktır. Bu mistik tasavvur, tasavvuf ehlinin vazgeçilmez ve bilinen ruh halinin tezahürüdür.

Mete'nin 'Yiğidi Gül Ağlatır' şirindeki anlam derinliği de benzer bir metafizik algının tasavvuru şeklinde karşımıza çıkmaktadır.

Yiğidi gül ağlatır gam öldürür

Nice namert ava çıksa, tuzak kursa, kurşun atsa;

Yiğidi çökertmezse kahır.

Bir dem yar hüzünle baksa

Bir gönül gözüyle baksa

Yiğidi gül ă̆latır, gam öldürür (Mete, 2011:26).

Mete'nin bu dizelerinde gördüğümüz 'gönül gözüyle bakmak' tabiri bize inanç dünyamızın, tasavvufi öğretinin temel unsurlarından olan;

- Ayn-ül Yakin 
- İlm-ül Yakin

- Hakk-ul Yakin

İlkelerini hatırlatır. Bu mistik, yani 'gözle görerek bilmek' ya da Yaratanı 'gönül gözü ile görebilmek' aşaması bir kul, bir mümin için son derece büyük bir aşamadır. İlm-ülyakin ile ilk aşamaya varan mümin, ayn-ülyakin ile ikinciaşamaya ve nihayet yok da yok olmaya, Hakk'ı bulmaya ulaşacaktır. Şairin yarattığı bu metaforik örgü, çağrışımları ile mistik dünyamızın derinliklerini işaret etmektedir.

Mete'nin bu duygularla kaleme aldığı bir diğer şiiri de 'Şehidin Destanı' adını taşır.

Fişekler patliyor güneş tutukhilal berrak

Dă̆ taş can evinden tekbir tekbir çă̆layarak

Sultanım seni uğurlar bu ebedi bayrak

Sen ki kevseri namluyla içtin ırmak ırmak

Sen bir köprü, düştün de geçit verdi uçurum

$\cdots$

Şehidim, ruhum, melekler katında alptuğum

Yemin dövüşte secdeye kırllan kalemin

Silahın bayrağın kuranın üstüne yemin

$\cdots$

Müjde ey toprak tuğbadır bu fidan bu civan

Şehidim ölümsüz fani gönüllerde divan

Ölmedin sen bir oluştur bu bir şanlı doğum

Kütüğü göklerde soyuna kurban olduğum (Mete, 2011:50).

Şiiri kuşatan duygu dünyası, görünürde baskın olarak milli duygulardır. Mete, hayatının ayrıntılarına inildiğinde ve ruh dünyası çözümlendiğinde mensubu olduğu millet bilinci ile tabi olduğu İslam inancını mecz eden bir anlayışa sahiptir. Dolayısıyla milli bir durum ile İslami bir kabulü harmanlayan bu şiirinde, mistizmin unsurlarından ve imkânlarından faydalanır. Vatanı, milleti ve tabi bunları çevreleyen ve kuşatan dini için can verenleri bizzat Kur'an, yani Allah överek, mertebelerin en yücesi ile muştular. Bu muştu şiire;

Sen ki kevseri namluyla içtin ırmak ırmak

Müjde ey toprak tuğbadır bu fidan bu civan

Şehidim ölümsüz fani gönüllerde divan (Mete, 2011:50). 
Mısraları ile yansır. Hadisler yoluyla bize ulaşan bilgiler doğrultusunda, 'tuba'nın kudret eliyle dikilmiş ve dalları cennet surlarından taşan bir ağaç olduğu ve bu ağacın unsurlarından cennet ehlinin elbiselerinin dikileceği bilinmektedir. Şiirde metaforik bir unsur olarak kullanılan bu metafizik bilgi, Mete'nin diğer şiirlerinde olduğu gibi onun dini- tasavvufi yönünü ortaya koyması bakımından önemlidir. Öte âlemin unsurlarını imgesel bağlamda mısralarına taşıyan şair, onlara muttali olmakla müjdelenen şehidin şanlı bahtına vurgu yapar.

Mete' nin şehide seslenirken, kullandı̆̆ı;

Ölmedin sen bir oluştur bu bir şanlı doğum (Mete, 2011:50).

Mısrası bu muttali olma durumuna işaret etmektedir. Yine şiirde geçen cennet, kevser, şehit, Kur'an, Hakk, Tuğba vb kelimeler, şiirin mistik atmosferinin ana unsurlarını teşkil eder. Şehitlik, alptuğ, silah, kırılan kalem vb kelimeler de şiirdeki milli atmosferin unsurlarını temayüz ettirir. Mete'nin bu yolla oluşturduğu sentez aslında onun dünya görüşünü de özetleyen duygu halidir.

Kırk biryaşın muhasebesini yaptığı ve 'hikemi' tarzda yazdığı şiirinde de Mete'nin bütün tezatlarını, ruh çatışmalarını, vehimlerini ve korkularını, metafizik kaygılarla sorguladığ görülür.

Mekruh şiirler işledim

Ve belki de haram Sen Tanri'yla aram

Kırk bir yaş burcunda

Zoraki

Baktım ki

Kırk bir kere estă̆furullah (Mete, 1991:25).

Burada İslami bir terbiye ve mistik bir tavırla Mete'nin kendisiyle yaptığ muhasebe halini görmekteyiz. Şairin yarattığı metafizik çerçevenin fikri alt yapısını oluşturan İslami literatürü kullanması bu şiirin dikkate değer özelliklerinden biridir. 'Sen Tanrı'yla aram' misrasinda, Allah yerine Tanrı kelimesini kullanması bu anlamda ayrıca önemlidir. Mete'nin siyasi kabullerinin izlerini taşıyan bu tavrı, aslında bütün hayatını ve anlayışını kuşatan "sentezci" görüşünün izlerini taşır. Böylece Mete'nin ruh dünyasını şekillendiren İslam inancı ve milli değerlerin şiire hâkim olduğu görülecektir. Kırk bir yaşını idrak ettiği süreçte bir haram- helal muhasebesi yapan şair, her müminin yaşaması gereken bir arınma halini yaşar. Bu durum aslında"günahkâr" olduğumuzun farkında olma halidir. Fakat yine Tanrı'nın takdiri ile bu durumdan kurtulabilme imkânımız bulunmaktadır. Bu da 'tövbe' kapısını çalmakla mümkündür. Mete tüm bu ayrıntılarla, ait olduğu mistik duyuş ve düşünüş dünyasının özelliklerini şiirine yansıtır. Şiirde bir imge olarak dikkat çeken;

'Burak mıydın, durak mıydın? (Mete, 1991:25). 
Mısrasındaki Burak, Hz. Peygamberin Mi'raca çıkarken kullandığı binek olarak İslami literatürde yer alır. Mete'nin mistik bir imge olarak Burak'1 kullanıyor olması yine hem onun ilham kaynağını işaret etmesi hem de ruh dünyasındaki derinlikleri işaret etmesi bakımından önemlidir. Burak'ı manevi olarak Allah'a yakınlaşma unsuru olarak tasavvur eden Mete, 'durak' kelimesini ise hayatın farklı aşamalarını temsil eden bir imge olarak kullanır.

Mete'nin 'İmdat' adını taşıyan şiiri de hem içerdiği mistik derinliği hem de biçim özellikleri ile dikkat çeker. Serbest nazmı bırakarak dörtlük biçiminde ve dokuzlu hece vezniyle yazdığı bu şiirinde şair bir mücrim edası ile yardım diler ve dua eder. Şiirin her dörtlüğün sonunda bir 'yakarış' mısrası ile karşılaşıyor olmamız bu anlamda önemlidir.

Vakit kamçıdır, yel ısırgan,

Terk etti hazdan hayır beni

Kara bulutlar yorgan yorgan

Allah'ım toptan siyır beni

$\cdots$

Yeter artık, sen buyur beni

$\cdots$

Kopar kendine ayır beni

$\cdots$

Bir sen adil, kayır beni

$\cdots$

Kadir sofranda doyur beni

$\cdots$

Var dostlarma duyur beni (Mete, 2011:110-111).

Zahirden bunalan bu ruh hali, metafizik bir sığınma alanı arar. Dua, bu sığınma ve manevi ilticanın en kuvvetli aracıdır. Mete yaşadığı âlemle, mutlak olan öte âlemin kesiştiği alandaki tezatları ve bu tezatların ruh dünyasında yarattığı vehimleri yaşar.

İslam inancı, bu inanç sistematiğinin temel ilkeleri, bu ilkelerin sosyal hayatla kesiştiği alanlar Mete'nin şiirinde sıkça yer alır. Bu tür şiirlerinde, gördüğü yanlışlık ve eksiklikleri korkusuzca dile getiren şair, bu içerikle yazdığı eserlerinde eleştirel tavır takınır. Bu eleştirel tavır, zorunlu olarak onu didaktik bir üsluba yöneltir. Toplumu, insanı bilinçlendirmek, iyiyi ve güzeli göstermek, doğruyu öğretmek kaygısı, onu toplumcu bir sanat anlayışına yönlendirir. Zaman zaman kürsüden va'z eden bir hoca edasıyla oluşturulan şiirleri, Safahat'ın öğretici üslubu ve son derece de derinlik arz eden manzumelerini hatırlatır gibidir. Günümüz Türkçesinin imkânları ve içten bir duyuşla kaleme alınmış bu şiirler, ferdi buhran ve vehimlerden, kaygılardan mülhemmiş gibi görünse de özünde içtimai bir maksada hizmet eder. 
Bu anlamda "Ayrılış" şiirindeki 'ezan' mevzusu, "Kaylule Suları" şirindeki 'peygamberimizin sünneti' konusu, "Müjde" şiirindeki 'şeyh-mürid' ilişkisi ve 'şeyhe bağlılık konusu, "Yusuf idim" şiirindeki Hz. Yusuf kıssasına atıf, hatta Hz. Davut'u hatırlatan ayrıntıları, "Diriliş" şiirindeki Müslümanlığın ve Müslümanların tekrar dirilip eski gücüne kavuşması arzusu ve yeni bir medeni anlayışla dirilmeleri isteği, "Sahur","Teravih" gibi şiirlerindeki temel İslami unsurların dini ve sosyal hayatımızdaki yerleri vb. konular, Mete'nin edebi anlayışını ve şiir dünyasını çevreleyen mistik duyuş ve düşünüşün izlerini taşımaktadır.

\section{SONUÇ}

Diğer edebi eserlerinin yanında, yazdığı veya danışmalığını yaptığı; Deliyürek, Ekmek Teknesi, Kurtlar Vadisi, Kurtlar Vadisi Pusu, Kurtlar Vadisi- Irak (Sinema filmi), Bizim Ev, Hayat Bağları gibi dizilerle Türk toplum hayatının en çok izlenen yapımlarına imza atmıştır.

$\mathrm{Bu}$ dizilere yerleştirdiği -Kurtlar Vadisi serisinde 'Ömer Baba', Ekmek Teknesi'nde 'Fırıncı Nusret Baba', Deliyürek'te 'Kuşcu'- yeni karakterlerle, o güne değin bu sektörde göz ardı edilmiş dini ve milli duygularla temerküz eden karakterleri hayata geçirmiştir.

Bu karakterler onları bütünleyen özellikleriyle rol-model olmuşlar, toplumun geniş kesimleri tarafından benimsenerek sevilmişlerdir.

Böylece sürekli eksikliği hissedilen ve sosyal hayatımızın ayrılmaz, bütünleştirici parçaları olan dini ve milli değerlerimiz topluma sevdirilmeye, doğru yönleri ile tanıtılamaya çalışılmıştır.

Yine aynı yolla, dini ve milli değerlerimizle ilgili neredeyse yerleşik hale getirilen yanlış inançlar, tutum ve davranışlar eleştirilerek, doğrusu okuyucuya ya da izleyiciye ulaştırılmıştır.

Bütün eserlerinde 'toplumsal fayda' prensibi ile hareket eden Mete, eser verdiği edebi türlerin tümünü düşüncelerini, tespitlerini ve eleştirilerini okuyucuya/izleyiciye ulaştırmada bir araç olarak görmüştür.

Şiirlerinde de benzer saiklerle hareket etmiş, özellikle dini konularda kürsüde va'z eden bir hoca hüviyetiyle karşımıza çıkmaktadır.

Şiirlerinin büyük bir bölümünde ilham kaynağı, İslam ve İslami ilkeleri olmuştur.

Bu tür şiirlerinde çoğu zaman, yanlış yorumların, bida'tların hâkimiyetine dikkat çekerek bunların düzeltilmesi gereğine vurgu yapmış, dolayısıyla şiirlerinin ve eserlerinin hemen hepsinde eleştirel bir tavır takınmıştır.

Zaman zaman Halk edebiyatının formlarını kullansa da genellikle serbest nazımla ve açık anlaşılır bir dilde şiirlerini kaleme almıştır. 


\section{Kaynakça}

Akyüz, K. (2017) Batı Tesirinde Türk Şiiri Antolojisi. İstanbul: İnkılap Yayınları.

Çeri, M. (2010). Kısaca “Ö.L”, Rengahenk, 13, 26.

Çetin, N. (2014). Şiir Çözümleme Yöntemi. Ankara: Öncü Yayınevi.

Eriş, M. (2010). Bir Kardeşi Kaybetmenin Ardından. Rengahenk, 13, 28-31.

Fikret, T. (2015) Rübab- 1 Şikeste ( Haz. Abdullah Uçman- Hassan Akay), İstanbul: Çağrı Yayınları.

Gök, Hasan Hüseyin. (2016). Ömer Lütfi Mete'nin Hayatı, Sanatı ve Eseleri, Yayınlanmış Yüksek Lisans Tezi, Uşak Üniversitesi, Sosyal Bilimler Enstitüsü, Uşak.

Kartal, E,\& Batuhan T. (2010). Ardından. Rengahenk, 13,48-51.

Kuveloğlu, D.(2010). Yerli ve Milli Kalabilen Gerçek bir Aydındı Ömer Lütfi Mete Hakk'a Yürüdü. Kardeş Kalemler Dergisi, 38, 11-13.

Mete, M.(2010). Geç Buldum, Çabuk Kaybettim. Kardeş Kalemler Dergisi, 38, 9-1.

Mete, Ö.L. (2007). Milliyetçilik Milliyetsizlik. İstanbul: Timaş Yayınları.

Mete, Ö.L. (2011). Gülce. İstanbul: Timaş Yayınları.

Tezcan, A. (2010). 'Ölüm de Uyandım Gülüm, Öldüm de Uyandım'. Kardeş Kalemler Dergisi, 38 , 17-18.

\section{E- Kaynaklar}

TRT

Ömer

Lütfi

Mete

Belgeseli

$(2012$,

Kasım,18).http://www.dailymotion.com/video/xv6oy3_omer-lutfi-mete-omeragabeybelgeseli_news.

(2011, Ocak 1). http://www.dailymotion.com/video/xgtjxu_ulke-tv- 2-bolum-gencomerler_creation adresinden 10 Ekim 2015 tarihinde elde edilmiştir.

(2011， Ocak 30). http://www.dailymotion.com/video/xgtk5b_ulke-tv-3-bolum-gencomerler_creation adresinden 10 Ekim 2015 tarihinde elde edilmiştir.

Üsküdar Belediyesi Ömer Lütfi Mete'yi Anma Programı (2011, Şubat 3).http://www.dailymotion.com/video/xgvmbm_uskudar-3-bolumgencomerler_creation adresinden 2 Ekim 2015 tarihinde alınmıştır.

Üsküdar Belediyesi Ömer Lütfi Mete'yi Anma Programı (2011,Şubat 4).http://www.dailymotion.com/video/xgw5y9_uskudar-4-bolum-gencomerler_ creation adresinden 2 Ekim 2015 tarihinde alınmıştır.

Erdoğan, M. Çizme Neyi Ezmeye Çalışıyorsun (2010, Temmuz- Ağustos). http://www.yagmurdergisi.com.tr/yazar/konular/mehmet-erdogan adresinden 20 Eylül 2015 tarihinde elde edilmiştir

\section{Kisaltmalar}

ADP: Açık Deniz Programı

ÖML: Ömer Lütfi Mete 